\title{
Effect of Gypsum and compost Application in Reclaiming Sodic soils at Small Scale Irrigation Farm in Bora District of East Shewa Zone, Oromia, Ethiopia
}

\author{
Kasahun Kitila*, Abay Chala and Mekkonnen Workina \\ Adami Tulu Agricultural Research Center, Batu, Ethiopia \\ Correspondence: kiyafenu@gmail.com
}

Received: 22 April 2020 Accepted: 12 May 2020

ULR: https://doi.org/10.38112/agw.2020.v08i01.005

\begin{abstract}
This experiment was conducted in Bora district of East Shoa Zone of Oromia, Ethiopia from 2017 to 2019 with the aim to evaluate the effect of sole and integrated application of Gypsum $\left(\mathrm{CaSo}_{4} \cdot \mathrm{H}_{2} \mathrm{O}\right)$ and compost as soil salinity amendment. Onion variety (Adama red), the most commonly produced crop by farmers, was used as the test crop. Three levels of compost $(0,2.5,5 \mathrm{t} / \mathrm{ha})$ and three levels of Gypsum $(0,2 \mathrm{t} / \mathrm{ha}$, and $4 \mathrm{t} / \mathrm{ha}$ gypsum) were factorial combined and arranged in RCBD design with three replications having an area of $3 \mathrm{mx} 4 \mathrm{~m}$ for each. It was identified that integrated application of $4 \mathrm{t} / \mathrm{ha}$ gypsum and 2.5 ton/ha compost produced economically optimum yield (396q/ha). The interaction effect of Gypsum integrated with compost in reducing soil sodicity indicators such as ESP(exchangeable sodium percentage), $\mathrm{Na}^{+}$ concentration, $\mathrm{pH}$, and $\mathrm{EC}$ were highly significant $(\mathrm{p}<0.05)$. Sole application of Gypsum was also significantly affect $(p<0.05)$ the level of ESP, $\mathrm{Na}^{+}, \mathrm{Ca}^{2+}$ and EC. ESP and EC were very high at the control treatment and showed a decreasing trend as the level of Gypsum requirement increases from $50 \%$ to $100 \%$. The main effect of compost significantly affected $(\mathrm{p}<0.05)$ the level of $\mathrm{pH}$ showing a decreasing trend as the level of compost was increased. Crop yield was increasing as the level of compost and gypsum application level were increasing indicating that both materials are very important for improvement of production and productivity of land affected by salinity problem. Therefore, considering its economical importance and positive effect in soil salinity amendment potential, $100 \% \mathrm{GR}$ integrated with 2.5 ton/ha compost was recommended as the best strategy in reclamation of salt affected soil.
\end{abstract}

Keywords: Soil salinity, Application, Gypsum, Compost, Reclamation, small scale Irrigation

\section{Introduction}

Soil degradation, which can be caused by salinity and sodicity, is considered as an environmental problem with severe adverse effects on agricultural productivity, particularly in arid and semiarid regions (Qadir et al., 2006). It is considered the most critical environmental stress which can negatively affect plant growth and the metabolism process (Rodriguez-Navarro and Rubio, 2006). Salinity usually appears in the arid and semi-arid areas where the evaporation process is higher than the total precipitation (Qadir et al., 2006). It was reported that groundwater is a permanent source of soil salinzation that causes poor productivity in the irrigated areas Moukhtar $e t$ al. (2003).

In Ethiopia, it was reported that, there are over 11 million hectares of unproductive naturally salt affected wastelands (Abdel- Fattah, 2012). It is the major problems in irrigated areas of arid and semi-arid region where there is a high evapotranspiration rate in relation to precipitation (Abas $e t$ al., 2016). This study also revealed that about 44 million ha (36\% of the country's total land areas) are potentially susceptible to salinity problems.
Bora district is found in the rift valley of Ethiopia where soil sodicity problem is very high due to higher evapotranspiration (Tamire, 2004). According to the study by Kasahun et. al. (2016), about $75 \%$ of the farmers in Bora district has been using ground water for irrigation that were found sodic based on FAO classification of salt affected soil and water. This study revealed that $\mathrm{pH}>8.5$, $\mathrm{EC}<4 \mathrm{ds} / \mathrm{m}$, and ESP $>31$ were recorded in these districts at the farmers who are using ground water for irrigation.

There are many procedures and strategies that can be used to improve salt affected cropland. One of the approaches for the economic utilization of moderately salt affected land is to grow salt tolerant plant species with appropriate agricultural practices (Mokoi and Verplancke, 2010). The chemical remediation is one of these reclamation strategies (Sharma and Minhas, 2005). The application of $\mathrm{Ca}$ amendments can improve different properties of soil and act as soil modifiers that can prevent development of sodicity which is directly related to plant growth, crop productivity and crop yields (Wong et al., 2009; Chintala et al., 2010). Specific chemical amendments such as calcium chloride $(\mathrm{CaCl} 2 \cdot 2 \mathrm{H} 2 \mathrm{O})$ and gypsum $(\mathrm{CaSO} 4 \cdot 2 \mathrm{H} 2 \mathrm{O})$ can be used as direct source for $\mathrm{Ca} 2+$ 
cation; however gypsum is normally available and relatively cheap. Gypsum plays a significant role in the reclamation of saline-sodic soils by providing a $\mathrm{Ca} 2+$ cation to replace the exchangeable $\mathrm{Na}+$ from the colloid's cation exchange positions and leaching it out from the root zone (Sharma and Minhas, 2005, Mohamed et al,. 2011). Soil salinity management interventions usually vary from place to place depending on the type of soil salinity, the availability of the materials and awareness on soil salinity management practices. Gypsum has become an efficient to reclaim sodic soils (Fisher and Madeline, 2011). The study indicated that, application of gypsum increases concentration of $\mathrm{Ca} 2+$ in soil solution to substitute the adsorbed sodium, hence overcome the dispersion effects of $\mathrm{Na}+$ and improve the soil structure in the dispersed soils.

Organic material amendments like application of compost increases soil $\mathrm{CO}_{2}$ concentrations and releases $\mathrm{H}+$ when it dissolves in water. The released $\mathrm{H}+$ enhances $\mathrm{CaCO} 3$ dissolution and liberates more calcium for sodium exchange (Ghafoor et al., 2008). The addition of compost in to salt affected soil has been successful in improving soil properties of sodic soils (Islam et al., 2017). However, the effect of integrated application of both compost and Gypsum for soil sodicity reclamation was not known. Objective of this study evaluate the impact of gypsum and compost application on reclamation of salt affected irrigated land and identification best application rate of Gypsum and compost for sodicity management.

The study was conducted in Bora District of East Shewa Zone of Oromia which is located $100 \mathrm{~km}$ far from capital city Addis Ababa to the south. Geographically located at $39.02 \mathrm{E}, 8.37^{\circ} \mathrm{N}$ (Kasahun et al., 2016). In this district, irrigation is the main economic activity for many small scale farmers and large scale investors. The district is generally characterized by dry low land agro-climate with the altitude ranging from $1676-1750 \mathrm{msl}$. The rainfall pattern is erratic, insufficient mean monthly precipitation and higher potential evapo-transpiration. Mean daily temperature is $20^{\circ} \mathrm{c}$ during the rainy season. Sandy loam is the dominant soil texture identified during the soil salinity assessment and characterization (Kasahun et. al., 2016). As far as vegetation is concerned, mid rift valley in general and Bora district in particular is characterized by scattered acacia wood lands.

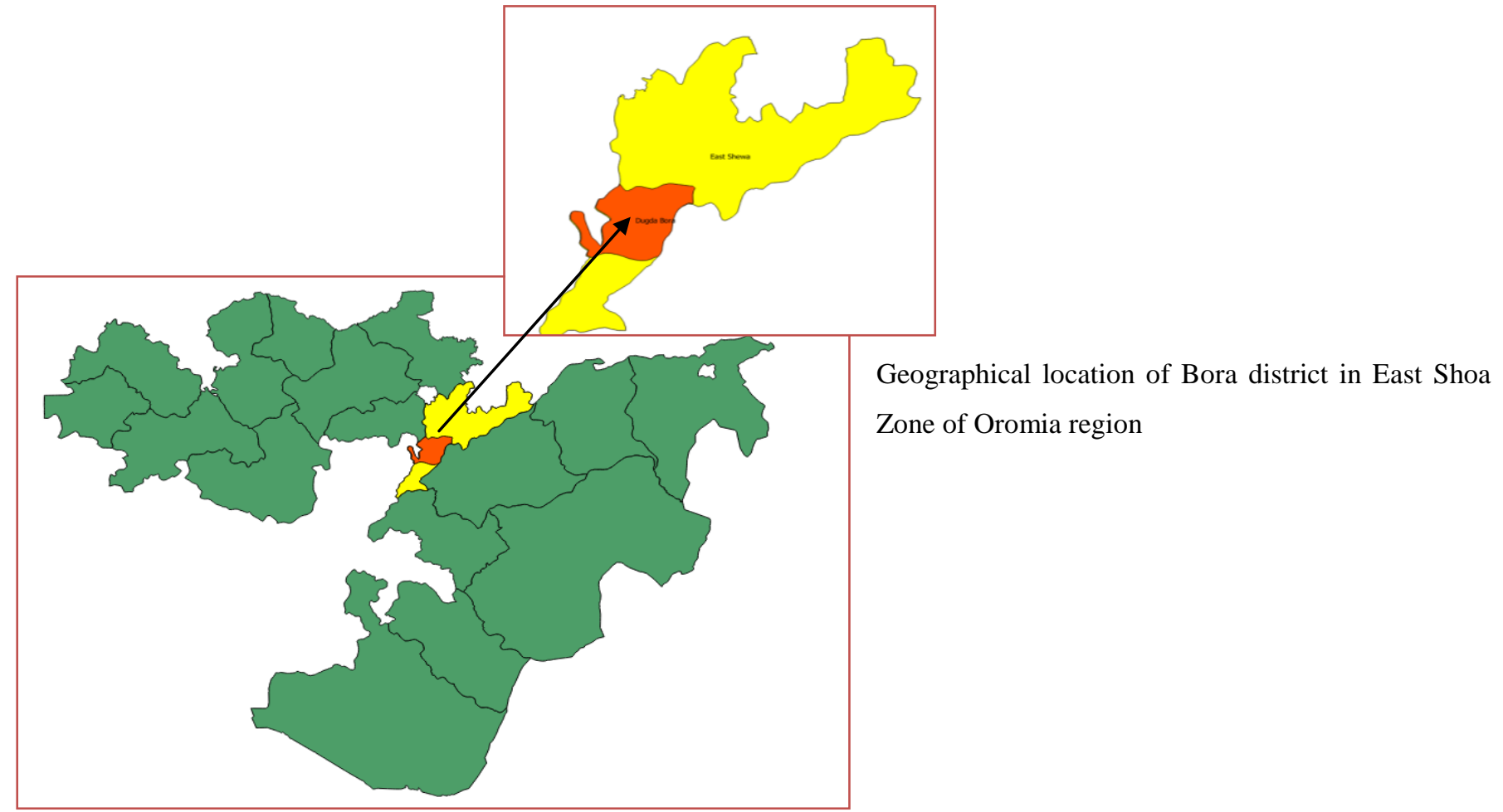




\subsection{Farmers Selection and Treatments}

Two farmers who are using ground water for irrigation were purposively selected depending on their interest for evaluation soil salinity management. In this trial, three levels of Gypsum requirement $(0,2$ and $4 \mathrm{t} / \mathrm{ha})$ and three levels of compost $(0,2.5$, and $5 \mathrm{t} / \mathrm{ha})$ were factorial combined. The level of Gypsum requirement was determined by the initial level of CEC, ESP initial, plan of ESP at final and 1.72t Gypsum which is the amount of Gypsum required to reduce a unit of sodium in the soil (Mohamed, 2012).

Therefore, Average CEC at initial was $17 \mathrm{meq} / 100 \mathrm{gm}$, ESP initial $=25 \%$, ESP final (required to be reached by reclamation $)=10 \%$

\subsection{Treatments}

1. Control (without compost and gypsum)

2. 2.5 ton/ha Compost

3. $5 \mathrm{t} / \mathrm{ha}$ Compost

4. $50 \%$ GR $(2 \mathrm{t} / \mathrm{ha})$

5. $100 \%$ GR $(4 \mathrm{t} / \mathrm{ha})$

Onion variety (Adama red), which is one of the major vegetable crops produced by the farmers in the area, was used as the test crop. The treatments were replicated three times having $12 \mathrm{~m}^{2}\left(3 \mathrm{~m}^{*} 4 \mathrm{~m}\right)$ area for each plot and arranged using RCBD. Site management (weeding, pesticide application, monitoring and watering) were done uniformly for all plots and experimental sites.

\subsection{Soil Sampling and Data Collection}

Soil samples were collected from each plot before application and after harvesting to the depth of $20 \mathrm{~cm}$ and were sent to soil laboratory for soil sodicity test. The extent of salinity before and after intervention were identified based on four main parameters such as EC (electrical conductivity), $\mathrm{pH}, \mathrm{ESP}$ (exchangeable sodium percentage), SAR (sodium adsorption ratio) because these values are used in the guidelines for classification of salt affected soil by different authors (Gonzalez et al., 2004; Qadir and Schubert, 2008). In addition, soluble cations such as CEC, Calcium, Magnesium, Sodium, and Potassium were analyzed. Crop yield was also taken and recorded to evaluate the effect of the treatments on total onion yield.
GR (Gypsum requirement) = (ESPiESPf $) / 100 * \mathrm{CEC}^{*} 1.72$ ton $=(25-10) / 100 * 17 * 1.72=4.3$ ton/ha

The level of compost was determined based on the amount of nitrogen fertilizer that the farmers are currently applying and the quality of conventional compost in terms of total nitrogen content. Accordingly, on average the farmers were using $100 \mathrm{~kg}$ urea $(46 \mathrm{~kg} \mathrm{~N} / \mathrm{ha})$ for onion. The quality of compost was determined after laboratory analysis; accordingly, it contained $1 \%$ total nitrogen. Therefore, about 4.6t/ha which is nearly 5ton/ha compost can supply or substitute $46 \mathrm{~kg} \mathrm{~N}$ ( $100 \mathrm{~kg}$ urea). About $200 \mathrm{~kg} / \mathrm{ha}$ NPS was used based on the farmers practice that was applied uniformly for all plots at all trial sites.

6. 2.5t/ha Compost+50\%GR (2t/ha)

7. $2.5 \mathrm{t} / \mathrm{ha}$ Compost $+100 \%$ GR (4t/ha)

8. $5 \mathrm{t} / \mathrm{ha}$ Compost $+50 \%$ GR (2t/ha)

9. $5 \mathrm{t} / \mathrm{ha} \quad$ Compost $+100 \% \mathrm{GR}$

(4t/ha) 
Table1: Guidelines for classification of salt affected soil and water (Gonzalez et al., 2004)

\begin{tabular}{|l|l|l|l|l|}
\hline Soil classification & $\begin{array}{l}\text { EC } \\
\text { DS/m }\end{array}$ & SAR & ESP & PH \\
\hline Sodic & $<4$ & $>13$ & $>15$ & $>8.5$ \\
\hline Saline & $>4$ & $<13$ & $<15$ & $<8.5$ \\
\hline Saline sodic & $>4$ & $>13$ & $>15$ & $<8.5$ \\
\hline
\end{tabular}

Sodium percentage calculated as:

$\mathrm{ESP}=[\mathrm{Na}+] * 100$ CEC

\section{Economic data}

The partial budget analysis was performed the standard methodology designed by (CIMMYT, 1988). Input cost (cost of chemical fertilizer, Gypsum, seedling and compost), cost for land preparation, and labor cost were considered. The Marginal rate of return (MRR), which measures the amount of benefit gained for additional unit of cost or investment, was used as major criteria and calculated as the ratio of change in net income from each treatment and the control to the change in total variable cost for the treatment and the control.

$M R R=($ NIT-NIC $) /($ TVCT-TVCC $), \quad$ Where MRR (Marginal rate of return), NIT (Net income from each treatment), NIC (Net income by the control), TVCT (Total variable cost for the treatment), TVCC (Total variable cost for the control)

5. Data Analysis: Finally, data were analyzed using SAS version 9.0 and MINITAB version 19 was used.

\section{Results and Discussion}

\subsection{Main and combined Effect of Gypsum and Compost on Crop yield}

Main effect for Gypsum and compost application were highly significantly $(\mathrm{p}<0.05)$ affected crop yield. Crop yield was also highly significantly $(\mathrm{p}<0.05)$ affected by the combined application of Gypsum and Compost. Maximum crop yield (439 q/ha) was obtained from the combined application of $5 \mathrm{t} / \mathrm{ha}$ compost and $4 \mathrm{t} / \mathrm{ha}$ Gypsum followed by 5 t/ha compost combined with 2 t/ha gypsum that could gain about $406.7 \mathrm{Q} / \mathrm{ha}$. It was identified that high crop yield) was obtained from the combined application as compared with the sole application of compost and gypsum (table 2). About $275.55 \mathrm{q} / \mathrm{ha}$ and $325.00 \mathrm{q} / \mathrm{ha}$ onion yield was obtained from sole application of compost and gypsum respectively. In addition, it was identified that sole application of sole gypsum could gain high crop yield as compared with sole application of compost indicating that gypsum application is highly important in management of salt affected soil (Table2). Low crop yield was obtained from the control treatment (237.18 $\mathrm{q} / \mathrm{ha}$ ) where neither compost nor Gypsum was applied. This is highly in agreement with previous study by (Hanay et al., 2004) in Tanzania. In this study, maize yield increased by $54.1 \%$ and $82.2 \%$ when compost and gypsum were applied alone respectively. However, combining the two amendments increased maize yield by $104.2 \%$. On the other hand, main effect for the year, interaction effect of year and treatments were not significant indicating that onion yield was not significantly affected by year variation (figure1)

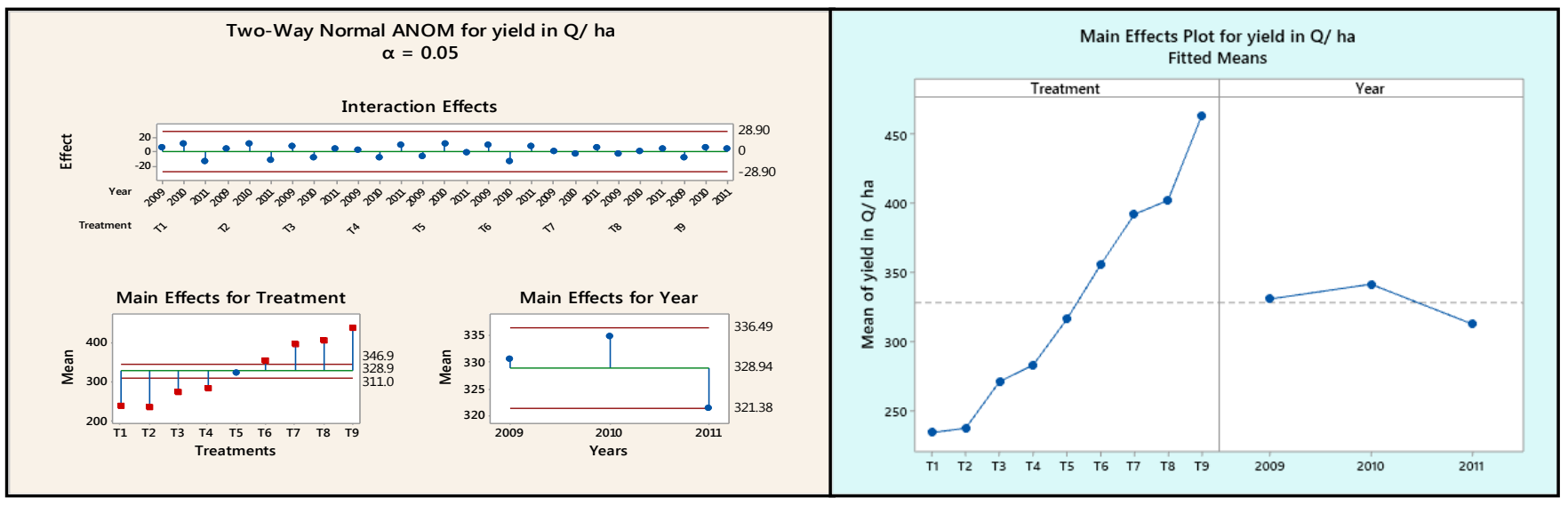


Kitila et al.

Figure1: Main and interaction effect of treatments and years

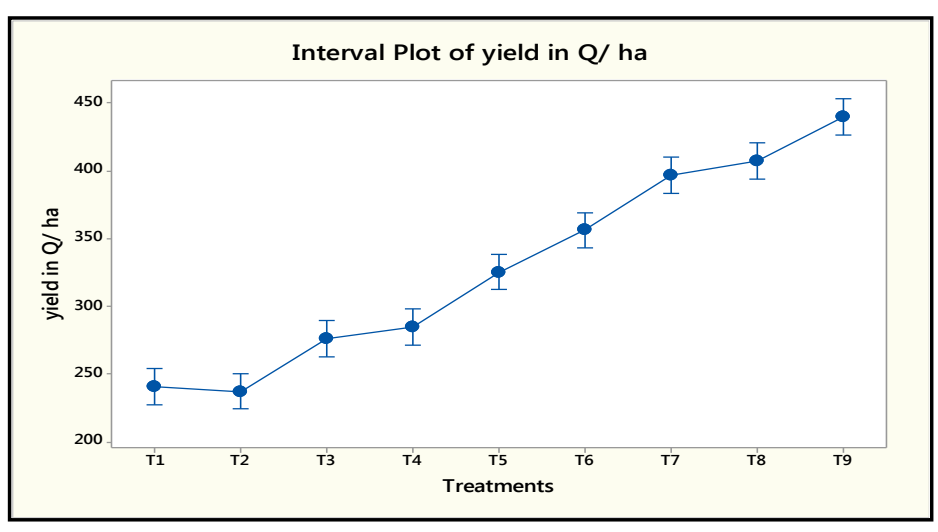

Figure2: Change in yield between the treatments

The crop yield showed an increasing trend with increased level of compost and gypsum (figure2). The relative yield advantage against check was calculated for each treatment (table2). Accordingly, the maximum crop yield advantage (85\%) was recorded at treatment 9 where 5t/ha compost applied in combination with 100GR (4t/ha). Similar study also showed that the yield efficiency of rice was increased by $46.6 \%$ for plot treated with gypsum and organic matter as compared with the control (Farook and Khan, 2010). Studies also indicated that combined application of gypsum and compost were the most effective combination to increase wheat grain by $208 \%$ over control (Zaka et al., 2003). Other similar studies by Joachim et.al. (2007) and Hanay et al., (2004) also indicated that combined application of gypsum and compost on salt affected soil significantly increased maize yield in Tanzania for two consecutive years as compared with sole application. Gypsum and compost applications to paddy saline soil is effective in improving soil physiochemical, biological properties and enhance the growth and crop yield of rice (Hanay et al., 2004; Tejada et al., 2006;

\begin{tabular}{|c|l|}
\hline \multicolumn{1}{|l|}{ No. } & Treatments \\
\hline 1. & Control \\
\hline 2. & 2.5 ton/ha Compost \\
\hline 3. & $5 \mathrm{t} / \mathrm{ha}$ Compost \\
\hline 4. & $50 \% \mathrm{GR}(2 \mathrm{t} / \mathrm{ha})$ \\
\hline 5. & $100 \% \mathrm{GR}(4 \mathrm{t} / \mathrm{ha})$ \\
\hline 6. & $2.5 \mathrm{t} / \mathrm{ha}$ Compost+50\%GR (2t/ha) \\
\hline 7. & $2.5 \mathrm{t} / \mathrm{ha}$ Compost $+100 \% \mathrm{GR}(4 \mathrm{t} / \mathrm{ha})$ \\
\hline 8. & $5 \mathrm{t} / \mathrm{ha}$ Compost $+50 \% \mathrm{GR}(2 \mathrm{t} / \mathrm{ha})$ \\
\hline 9. & $5 \mathrm{t} / \mathrm{ha}$ Compost $+100 \% \mathrm{GR}(4 \mathrm{t} / \mathrm{ha})$ \\
\hline
\end{tabular}

Wong et al., 2009). Other similar study by Kasahun et al. (2019) found that combined application of compost and gypsum significantly increased onion yield. Beneficial effect of compost on crop growth and yield has been reported. However, combinations of chemical amendments (gypsum) with compost were more beneficial to cut short the reclamation period and for achieving rapid rehabilitation (Ameen, et al., 2017).

An increased in crop yield is mainly due to application of Gypsum as calcium amendments can prevent the development of sodicity which is directly related to plant growth, crop productivity and crop yields (Wong et al., 2009). Studies showed that soluble $\mathrm{Ca} 2+$ released by gypsum can be used to reduce the stress effect of $\mathrm{Na}+$ on crop yield (Chi et al., 2012). It was known that $\mathrm{Ca} 2+$ have a stronger charge than $\mathrm{Na}+$ they will replace $\mathrm{Na}+$ on exchange sites, causing $\mathrm{Na}+$ to be released to the soil solution and be susceptible to removal by leaching. Compost also plays an important role in improving soil quality, structure, basic infiltration rate and nutrient enhancement which resulted in increased crop yield (Saied et al. 2017). 
Table 2: Effect of compost integrated with Gypsum on onion yield.

\begin{tabular}{lllllll}
\hline Treatments & $\begin{array}{l}\text { Mean Crop } \\
\text { yield }(\mathrm{Q} / \mathrm{ha})\end{array}$ & $\begin{array}{l}\text { SE } \\
\text { Mean }\end{array}$ & St.Dev & Minimum & Maximum & $\begin{array}{l}\text { Relative yield } \\
\text { advantage }\end{array}$ \\
\hline Main effect for Compost & & & & & & \\
0 (control) & $237.18^{\mathrm{f}}$ & 7.01 & 21.02 & 215 & 275 & 0.00 \\
2.5t/ha compost & $240.03^{\mathrm{f}}$ & 7.55 & 22.65 & 191.67 & 260 & 1.20 \\
5t/ha compost & $275.55^{\mathrm{e}}$ & 8.20 & 25.60 & 216.7 & 285 & 16.18 \\
Main effect for Gypsum & & & & & & \\
2t/ha Gypsum & $284.44^{\mathrm{e}}$ & 4.44 & 13.33 & 265 & 300 & 19.93 \\
4t/ha Gypsum & $325.00^{\mathrm{d}}$ & 4.82 & 14.46 & 310 & 350 & 37.03 \\
Interaction effects & & & & & & 50.00 \\
2.5t/ha compost+2t/ha Gypsum & $355.77^{\mathrm{c}}$ & 6.33 & 18.99 & 330 & 397 & 67.13 \\
2.5t/ha compost+4t/ha Gypsum & $396.40^{\mathrm{b}}$ & 2.59 & 7.77 & 385 & 410 & 81.47 \\
5t/ha compost+2t/ha Gypsum & $406.70^{\mathrm{b}}$ & 3.05 & 9.14 & 395 & 425 & 85.23 \\
5t/ha compost+4t/ha Gypsum & $430.33^{\mathrm{a}}$ & 4.18 & 12.53 & 421 & 458 & \\
LCD $(0.05)$ & 25.03 & & & & & \\
CV $(\%)$ & 6.05 & & & & & \\
T-test & $* * *$ & & & & & \\
\hline
\end{tabular}

6.2 Main and combined Effect of Gypsum and Compost on EC

The level of Electrical conductivity (EC) of the soil is one of an indicator to describe its salinity status. It was identified that main effects for Gypsum and its interaction with compost significantly $(\mathrm{p}<0.05)$ affected EC $(\mathrm{mmhoms} / \mathrm{cm})$ of the soil. Low EC $(0.36 \mathrm{mmhoms} / \mathrm{cm})$ was recorded from treatment nine where 5t/ha compost was applied combined with $100 \%$ GR (4t/ha). Maximum EC (3.78 mmhoms/cm) was recorded under the control treatment where neither compost nor gypsum was applied (Table3). EC was not significantly affected by the main effect year indicating that variation in cropping season has no an effect on the level of EC (figure 3). On the other hand, main effect compost was not significantly affected the level of EC but it showed a decreasing trend as the level of compost application was increasing (table3). Other similar studies also revealed that, the application of compost accelerated sodium leaching by increasing CEC of the soil that consequently reduced EC of the soil (Bardhan et al., 2007).
EC showed decreasing by $92 \%$ (from 3.78 $\mathrm{mmhos} / \mathrm{cm}$ to $0.36 \mathrm{mmhos} / \mathrm{cm}$ ) as the levels of gypsum and compost level of application was increasing (table4). This was due to reduced concentration of dissolved sodium as a result of gypsum application (Tejada et al., 2006). Similar study also revealed that the integrated application of compost and gypsum reduced EC by $31 \%$ as compared with sole application of compost and gypsum (Niazi et al., 2001). It was identified that EC of the soil insignificantly affected $(p<0.05)$ by sole application of compost but highly significantly affected $(\mathrm{p}<0.05)$ by sole application of gypsum (table 3 ). The result was mainly due to the fact that gypsum plays a significant role in the providing a $\mathrm{Ca} 2+$ cation to replace the exchangeable $\mathrm{Na}+$ on the exchange positions and leaching it out from the root zone (Sharma and Minhas, 2005). EC of the soil before treatment application was not significantly $(\mathrm{p}<0.05)$ different indicating that the experimental plots have similar EC (Table3). 
Figure 3: Change in EC after application of the treatments

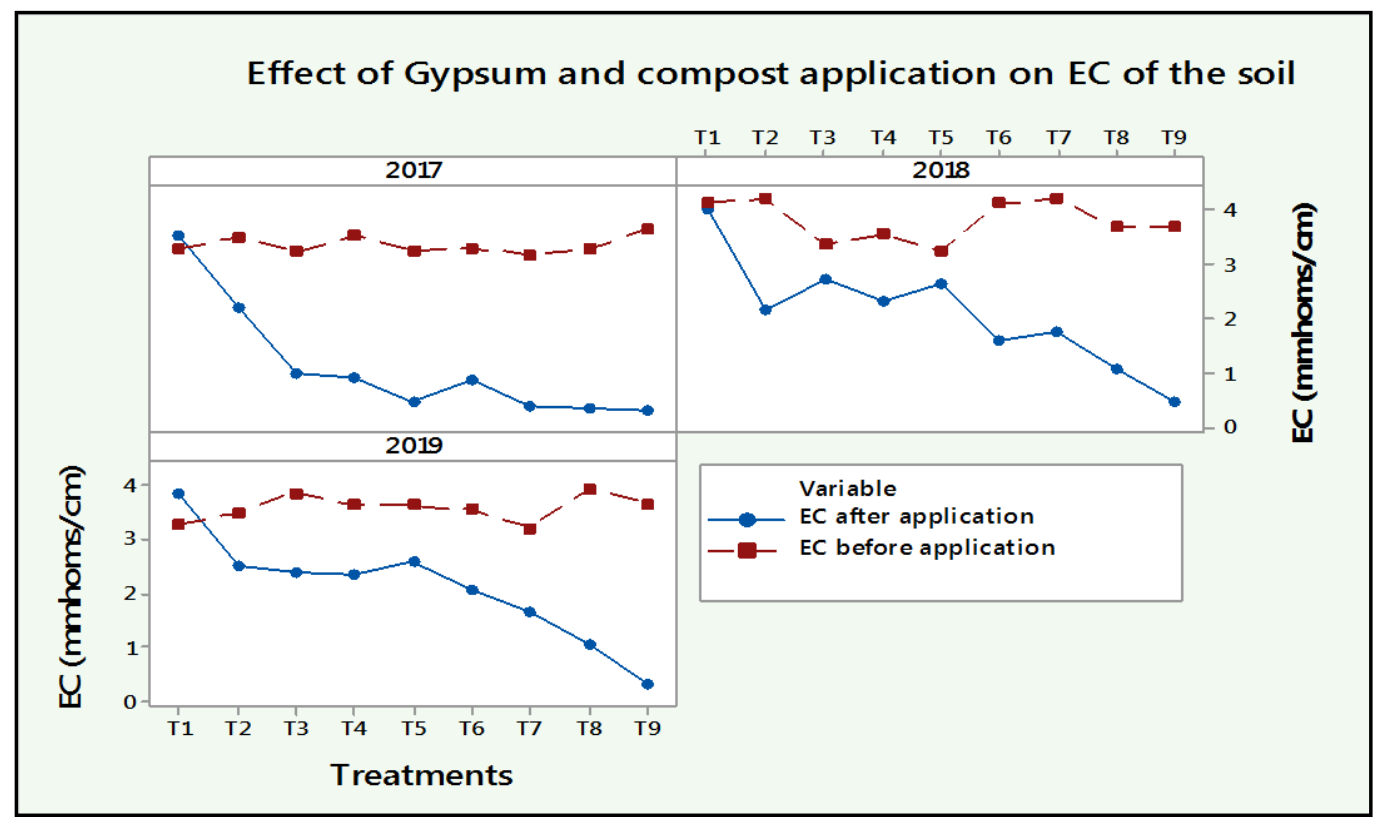

Treatments: 1. Control 2. 2.5 ton/ha Compost 3. 5t/ha Compost 4. 50\% GR (2ton/ha) 5. $100 \%$ GR (4ton/ha) 6. 2.5t/ha Compost+50\%GR 7. 2.5t/ha Compost $+100 \%$ GR 8. 5t/ha Compost +50\%GR 9. 5t/ha Compost $+100 \%$ GR

Decreased soil dispersion and lower EC were recorded more in combined application of gypsum and compost than sole application of gypsum and compost (Ghulam et al., 2011).

Exchangeable sodium percentage (ESP) is the amount of adsorbed sodium on the soil exchange complex expressed in percent of the cation exchange capacity in milli equivalents per $100 \mathrm{~g}$ of soil. In other words, it is the percentage of soil exchange sites occupied by $\mathrm{Na}^{+}$, and is calculated by dividing the concentration of $\mathrm{Na}^{+}$cations by the total cation exchange capacity (Qadir et al., 2008).

Exchangeable sodium percentage (ESP\%)

$$
=\frac{\text { Exchangeable } \mathrm{Na}(\mathrm{me} / 100 \mathrm{~g} \text { soil })}{\text { Cation exchange capacity }(\mathrm{me} / 100 \mathrm{~g} \mathrm{soil})} \times 100
$$

It was identified that the main effect for gypsum
The study by Muhammad et al. (2018) indicated that integrated application of Gypsum and compost reduced $\mathrm{EC}$ of the soil from $8.52 \mathrm{dS} \mathrm{m}^{-1}$ to $3.0 \mathrm{dS} \mathrm{m}$. The reduction of EC might be due to leaching of soluble salts $\left(\mathrm{Na}^{+}\right)$into the drainage systems or into the deeper layers of the soil profile (Hanay et al., 2004).

\subsection{Main and combined Effect of Gypsum and Compost on Exchangeable Sodium (ESP)}

significantly $(\mathrm{p}<0.05)$ affected ESP. On the other hand, main effect for compost was not significantly affected ESP at similar significance level. The combined effect of Gypsum and compost were highly significantly $(p<0.05)$ affected ESP. Low ESP $(1.46 \%)$ was recorded from treatment nine where $5 \mathrm{t} / \mathrm{ha}$ compost applied combined with $100 \% \mathrm{GR}(4 \mathrm{t} / \mathrm{ha})$ followed by treatment seven $(1.63 \%)$ that received $2 \mathrm{t} / \mathrm{ha}$ compost and $4 \mathrm{t} / \mathrm{ha}$ gypsum. Maximum ESP (15.97\%) was recorded from the control treatment that received neither compost nor gypsum (table4). ESP of the soil before treatment application was not significantly $(p<0.05)$ different indicating that the experimental plots have similar ESP (table3). 
Figure 4: Change in ESP after application of the treatments

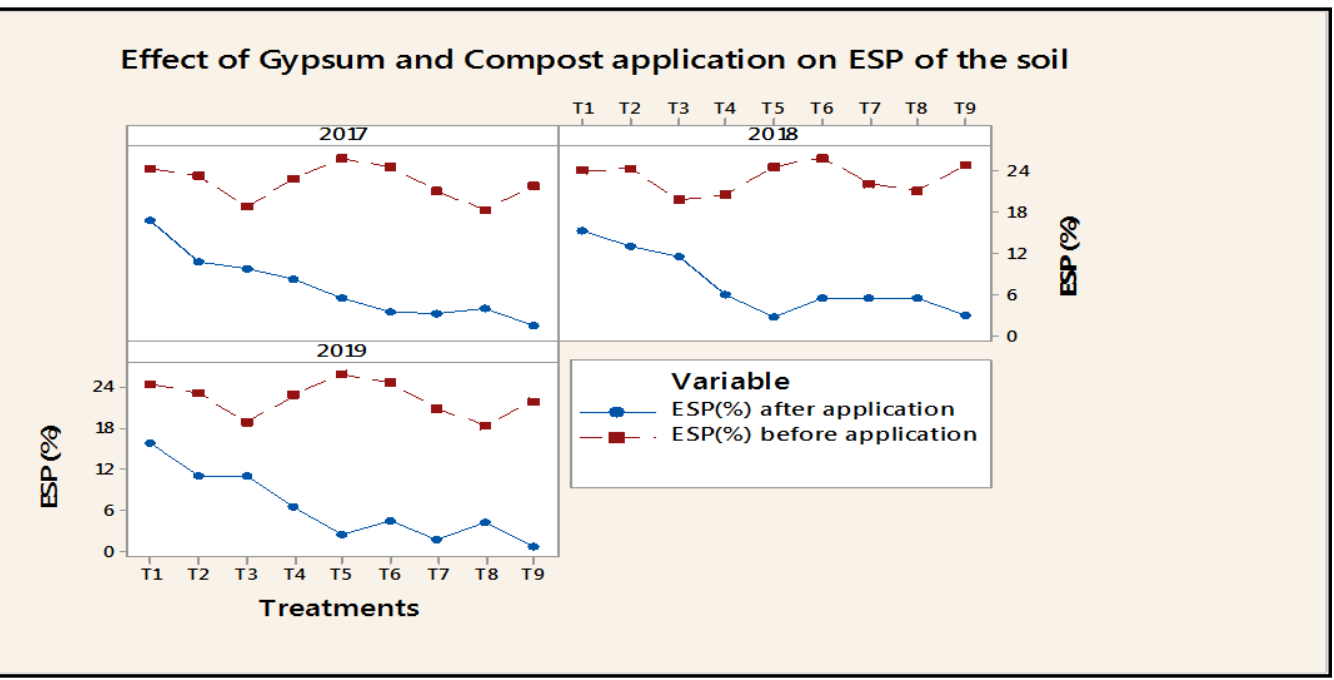

Treatments: 1. Control 2. 2.5 ton/ha Compost 3. 5 t/ha Compost 4. 50\%GR $(2$ ton/ha $)$ 5. 100\%GR (4ton/ha) 6. 2.5t/ha Compost $+50 \% G R \quad$ 7. $2.5 t / h a$ Compost $+100 \%$ GR 8. 5t/ha Compost $+50 \% G R 9$. 5t/ha Compost $+100 \%$ GR

The levels of ESP showed decreasing trends as the level of compost and gypsum application were increasing (figure 4).However; ESP was not significantly different with the variation in year or cropping seasons. The reduced in ESP was mainly due to adding of Ggpsum releases exchangeable $\mathrm{Ca}^{2+}$ to replace $\mathrm{Na}^{+}$on exchange sites, causing $\mathrm{Na}^{+}$to be leached to the soil solution (Abbas et al., 2016). Other similar studies also indicated that use of gypsum integrated with organic material like water hyacinth compost and rice straw compost reduced ESP of saline- sodic soils as compared their sole application (Shaaban et al., 2013; Abay and Kasahun, 2019).

\subsection{Main and combined Effect of Gypsum and Compost on Ex.Calcium (Ca2+)}

Main effect for gypsum was significantly $(\mathrm{p}<0.05)$ affected $\mathrm{Ca} 2+$ concentration in the soil. On the other hand, $\mathrm{Ca} 2+$ was not significantly $(\mathrm{p}<0.05)$ affected by sole application of compost (table3). However, $\mathrm{Ca} 2+$ level increased with the increased level of compost mainly due to addition of few amount of calcium and improved CEC due to compost application (Clark et al., 2007). The interaction effect of Gypsum and compost on the level $\mathrm{Ca} 2+$ were highly significant $(\mathrm{p}<0.05)$ different indicating that the level of $\mathrm{Ca}+2$ level significantly affected by the sole application of gypsum (Table3)

Figure 5: Residual effect of compost and gypsum application on Ex. Ca+2 across the years

Effect of Gypsum and compost application on Ex.Ca (meq/100)

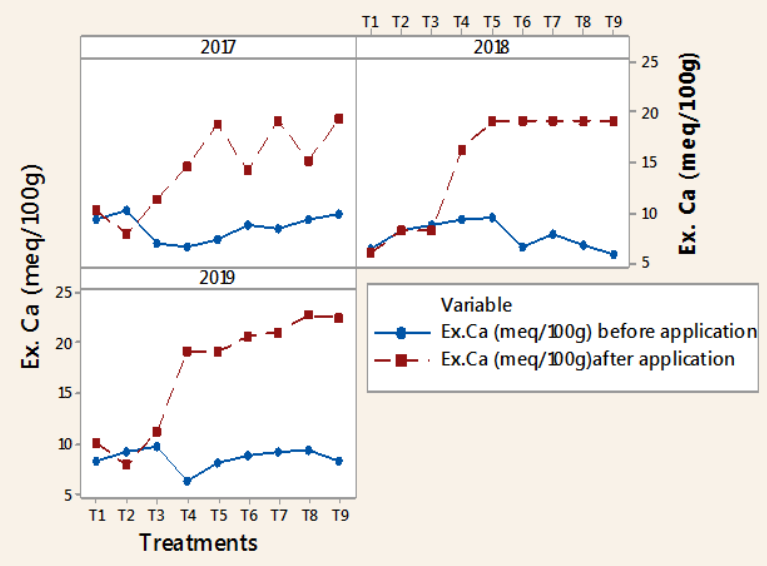

Effect of Gypsum and Compost application on Ex. Ca(meq/100g)

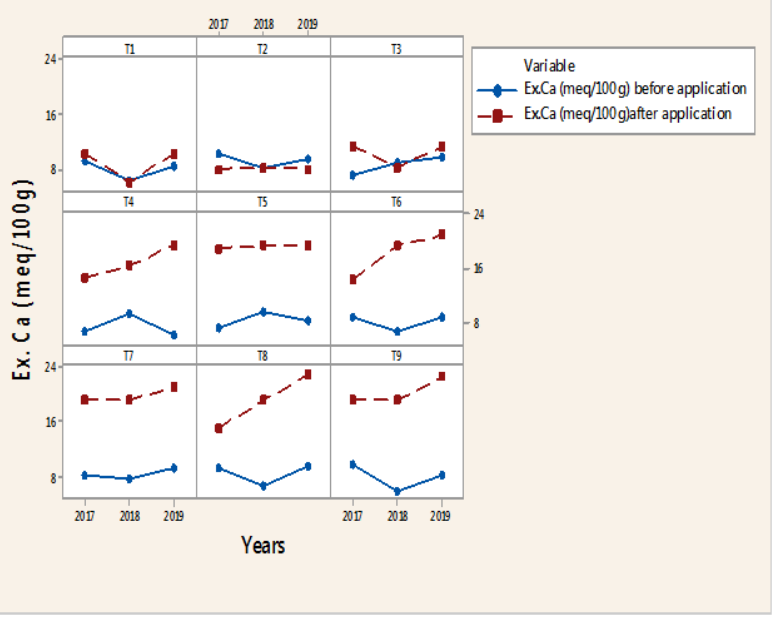


Treatments: 1. Control 2. 2.5 ton/ha Compost 3. 5t/ha Compost 4. 50\%GR (2ton/ha) 5. $100 \%$ GR $\begin{array}{lll}\text { (4ton/ha) } & \text { 6. } 2.5 \mathrm{t} / \mathrm{ha} \text { Compost }+50 \% \mathrm{GR} & \text { 7. } 2.5 \mathrm{t} / \mathrm{ha}\end{array}$ Compost +100\%GR 8. 5t/ha Compost +50\%GR 9. 5 t/ha Compost $+100 \%$ GR

Low $\mathrm{Ca} 2+(7.9 \mathrm{meq} / 100 \mathrm{~g})$ was recorded from the control treatment where neither compost nor gypsum was applied. Maximum Ca2+ $(24.55 \mathrm{meq} / 100 \mathrm{~g})$ was recorded from treatment nine where $5 \mathrm{t} / \mathrm{ha}$ compost applied integrated with $100 \% \mathrm{GR}$ (4t/ha) followed by treatment seven which was recorded $23.02 \mathrm{meq} / 100 \mathrm{~g}$.
$\mathrm{Ca} 2+$ of the soil before treatment application was not significantly $(p<0.05)$ different indicating that the experimental plots have similar $\mathrm{Ca} 2+($ table 3$)$. The level $\mathrm{Ca} 2+$ showed an increasing trend as the level of combined application of compost and gypsum were increased (figure5). It was increased to $107 \%$ where $5 \mathrm{t} /$ ha compost was applied in combination with $4 \mathrm{t} / \mathrm{ha}$ gypsum (table4). This result seems nearly agreement with (Sharma and Minhas 2005) who found that in addition to removing exchangeable $\mathrm{Na}+$, application of gypsum increased the concentration of $\mathrm{Ca} 2+$ in the soil. 
Agriways 8 (1) :28-44. 2020

Table 3: Mean separation on effect of Gypsum and Compost application on Soil salinity

\begin{tabular}{|c|c|c|c|c|c|c|c|c|}
\hline \multirow[t]{2}{*}{ Treatments } & \multicolumn{8}{|c|}{ Dependent variables } \\
\hline & $\begin{array}{l}\text { Initial } \\
\mathrm{EC}(\mathrm{mmho} \\
\mathrm{ms} / \mathrm{cm})\end{array}$ & $\begin{array}{l}\text { Residual } \\
\mathrm{EC}(\mathrm{mmho} \\
\mathrm{ms} / \mathrm{cm})\end{array}$ & $\begin{array}{l}\text { Initial } \\
\text { ESP } \\
(\%)\end{array}$ & $\begin{array}{l}\text { Residual } \\
\text { ESP }(\%)\end{array}$ & $\begin{array}{l}\text { Initial } \\
\text { Ex.Ca+2 } \\
(\mathrm{meq} / 100 \mathrm{~g})\end{array}$ & $\begin{array}{l}\text { Residual } \\
\text { Ex.Ca+2 } \\
(\mathrm{meq} / 100 \mathrm{~g})\end{array}$ & $\begin{array}{l}\text { Initial } \\
\mathrm{pH}\end{array}$ & $\begin{array}{l}\text { Residual } \\
\mathrm{pH}\end{array}$ \\
\hline \multicolumn{9}{|l|}{ Main effect for compost } \\
\hline 0 (control) & 3.80 & $3.78^{\mathrm{a}}$ & 16.01 & $15.97^{\mathrm{a}}$ & 8.02 & $7.93^{\mathrm{b}}$ & 8.43 & $8.32^{\mathrm{a}}$ \\
\hline $2.5 \mathrm{t} / \mathrm{ha}$ compost & 3.72 & $3.28^{\mathrm{a}}$ & 15.23 & $13.60^{\mathrm{a}}$ & 11.02 & $8.75^{\mathrm{b}}$ & 8.48 & $7.95^{\mathrm{a}}$ \\
\hline 5t/ha compost & 3.92 & $2.52^{\mathrm{a}}$ & 14.95 & $12.70^{\mathrm{a}}$ & 8.43 & $10.19^{\mathrm{b}}$ & 8.35 & $7.60^{\mathrm{b}}$ \\
\hline \multicolumn{9}{|l|}{ Main effect for Gypsum } \\
\hline 2t/ha Gypsum & 4.11 & $1.90^{\mathrm{b}}$ & 20.35 & $6.87^{\mathrm{b}}$ & 10.33 & $17.62^{\mathrm{c}}$ & 8.20 & $8.41^{\mathrm{a}}$ \\
\hline 4t/ha Gypsum & 3.28 & $0.68^{\mathrm{c}}$ & 19.35 & $3.61^{\mathrm{cd}}$ & 12.5 & $21.02^{\mathrm{a}}$ & 8.41 & $8.37^{\mathrm{a}}$ \\
\hline \multicolumn{9}{|l|}{ Interaction effects } \\
\hline $\begin{array}{l}2.5 \mathrm{t} / \mathrm{ha} \text { compost }+2 \mathrm{t} / \mathrm{ha} \\
\text { Gypsum }\end{array}$ & 4.3 & $1.70^{\mathrm{b}}$ & 18.35 & $4.55^{\mathrm{d}}$ & 10.2 & $17.80^{\mathrm{c}}$ & 8.13 & $7.94^{\mathrm{a}}$ \\
\hline $\begin{array}{l}2.5 \mathrm{t} / \mathrm{ha} \text { compost }+4 \mathrm{t} / \mathrm{ha} \\
\text { Gypsum }\end{array}$ & 3.35 & $0.92^{\mathrm{c}}$ & 15.68 & $1.63^{\mathrm{c}}$ & 11.58 & $23.02^{\mathrm{a}}$ & 8.33 & $7.90^{\mathrm{a}}$ \\
\hline $\begin{array}{l}\text { 5t/ha compost }+2 \mathrm{t} / \mathrm{ha} \\
\text { Gypsum }\end{array}$ & 3.57 & $1.65^{\mathrm{b}}$ & 19.36 & $4.52^{\mathrm{d}}$ & 11.58 & $17.90^{\mathrm{c}}$ & 8.35 & $7.89^{\mathrm{a}}$ \\
\hline $\begin{array}{l}\text { 5t/ha compost }+4 \mathrm{t} / \mathrm{ha} \\
\text { Gypsum }\end{array}$ & 4.01 & $0.36^{\mathrm{c}}$ & 20.5 & $1.46^{\mathrm{c}}$ & 11.85 & $24.55^{\mathrm{a}}$ & 8.43 & $7.87^{\mathrm{a}}$ \\
\hline $\mathrm{LCD}(0.05)$ & 0.72 & 1.12 & 4.01 & 2.88 & 2.32 & 3.79 & 0.35 & 0.50 \\
\hline CV $(\%)$ & 12.79 & 18.4 & 11.43 & 20.27 & 18.75 & 16.21 & 2.82 & 4.09 \\
\hline F-test & $\mathrm{ns}$ & $* * *$ & Ns & $* * *$ & ns & $* * *$ & $\mathrm{~ns}$ & $* *$ \\
\hline
\end{tabular}


Kitila et al.

Table 4: Relative change of soil salinity after application of compost and Gypsum

salts and take up pure water. Additionally, if salinity in

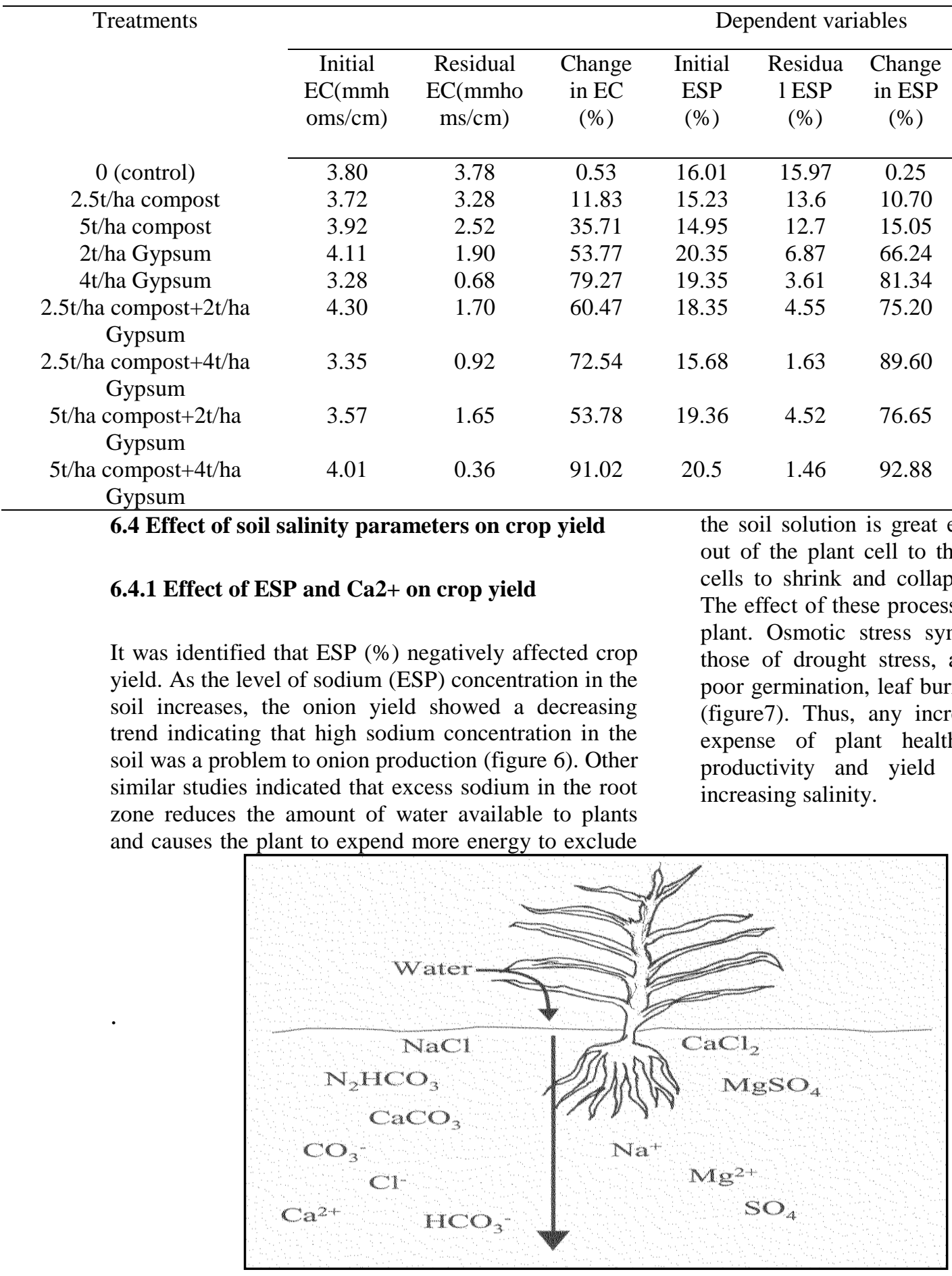

Figure7: Increased salts in root zone can result in decreased water uptake by plant 
On the other hand, $\mathrm{Ca} 2+$ has positive relationship with the crop yield. Crop yield showed an increasing trend as the level of $\mathrm{Ca} 2+$ in the soil was increasing (figure 6). An increased in yield was mainly due to the fact that $\mathrm{Ca} 2+$ is an important mineral for plant growth and health that consequently improve crop yield (Wright et al., 2008). ESP (\%) and $\mathrm{Ca} 2+$ have a negative relationship. ESP $(\%)$ showed a decreasing trend as the level of $\mathrm{Ca} 2+$ was increasing (Figure 6). Similar studies by different authors also indicated that the increase in $\mathrm{Ca}^{2}{ }^{+}$occurred due to direct application of gypsum (Wright et al., 2018). In this case, $\mathrm{Ca}^{2+}$ replaced $\mathrm{Na}^{+}$on exchange sites that was leached down during continuous irrigation so that there was net increase in $\mathrm{Ca} 2+$ content and very high decrease in the amount of $\mathrm{Na}+$ from the soil solution (El-Sanat et al., 2017).

Figure 6: Matrix plot of Onion yield in Q/ha, ESP (\%), and Ex. Ca2+ (Meq/100g)

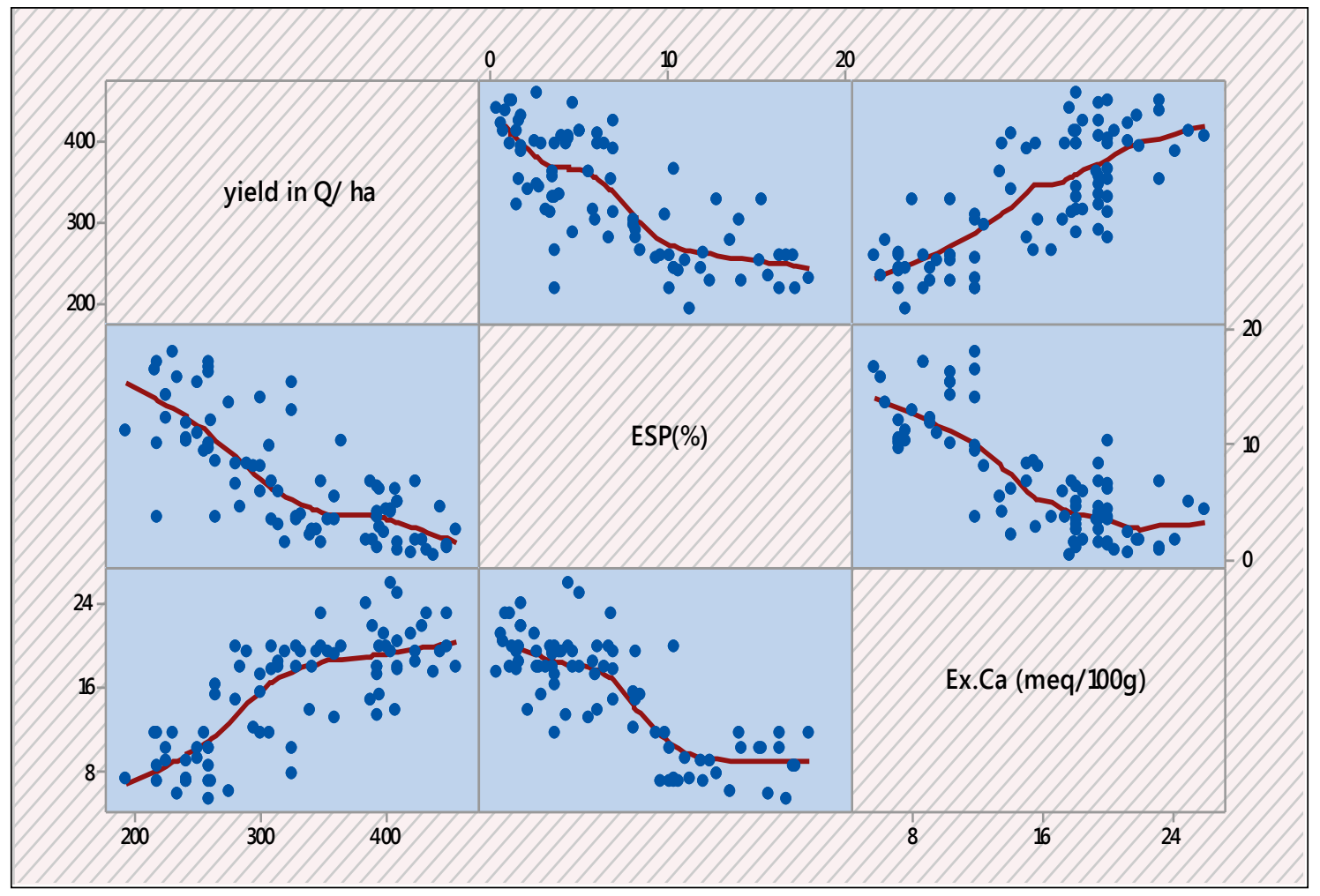

\subsubsection{Effect of EC and $\mathrm{Na}+$ on crop yield}

Both $\mathrm{EC}$ and $\mathrm{Na}+$ have negative relation with crop yield. As the level of $\mathrm{Na}+$ increases the EC of the soil increased that consequently reduced crop yield (figure 8). Onion yield showed a reduced trend as the level of $\mathrm{Na}+$ and EC of the soil is increased. That is why soil salinity management was required which aimed to reduce the concentration of $\mathrm{Na}+$ and $\mathrm{EC}$ in the soil. Other similar findings also showed that gypsum and compost applications to saline soil are an effective remediation procedure not only in terms of improving the physical, chemical and biological properties of the soil but also used to enhance the growth and development of crops (Wong et al., 2009). Combined application of compost and gypsum were superior ameliorants to reduce $\mathrm{EC}$ and $\mathrm{Na}+$ of the soil as compared with their sole application (Hanay et al., 2004). 
Figure 8: Matrix plot of Onion yield in Q/ha, EC (mmhoms/cm), and Ex. Na+ (Meq/100g)

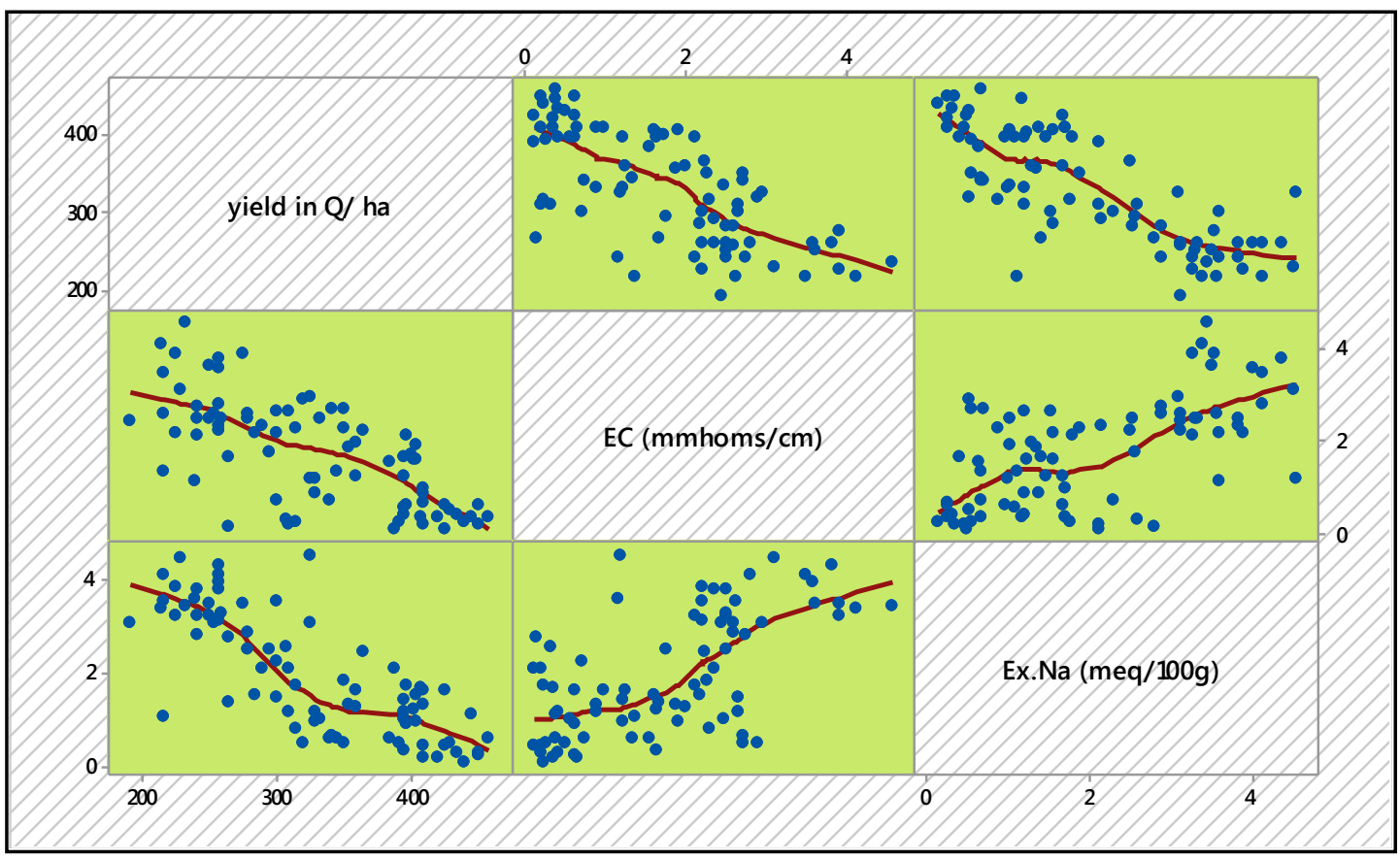

\subsubsection{Effect of Compost and Gypsum application on Soil pH}

Soil $\mathrm{pH}$ is a characteristic that describes the relative acidity or alkalinity of the soil. Soils are considered acidic if $\mathrm{pH}<5$, and very acidic if $\mathrm{pH}<4$. On the other hand, soils are considered alkaline if $\mathrm{pH}>7.5$, and very alkaline if $\mathrm{pH}>8$. Soil $\mathrm{pH}$ was highly significantly different $(\mathrm{p}<0.05)$ among the treatments. $\mathrm{pH}$ was very high at the control treatment (8.42), where there was no application of gypsum and compost as compared with other treatments (table). It was identified that the main effect of compost significantly ( $<<0.05$ affect soil $\mathrm{pH}$ ) different. Soil $\mathrm{pH}$ showed a decreasing trend as the level of compost was increased from 2.5 to 5 ton/ha
(Table3). This is mainly due to the fact that application of compost can reduce soil $\mathrm{pH}$ as a result of organic acids released during decomposition of compost (Abbas et al., 2016). On the other hand main and interaction effect gypsum was not significantly $(\mathrm{p}<0.05)$ affect soil $\mathrm{pH}$. This is mainly due to an increased in concentration of calcium from gypsum application has little influence in reducing soil $\mathrm{pH}$ (Brady and Weil, 2002). Studies also indicated that compost decreased soil $\mathrm{pH}$ by $9.5 \%$, gypsum by $3.9 \%$. Other similar studies also showed that $\mathrm{pH}$ was lowered by $5.7 \%$ when compost and gypsum were applied in combined form as compared with the control treatments (Niazi et al., 2001). 
Figure 9: Matrix plot of crop yield vs soil pH, EC and ESP

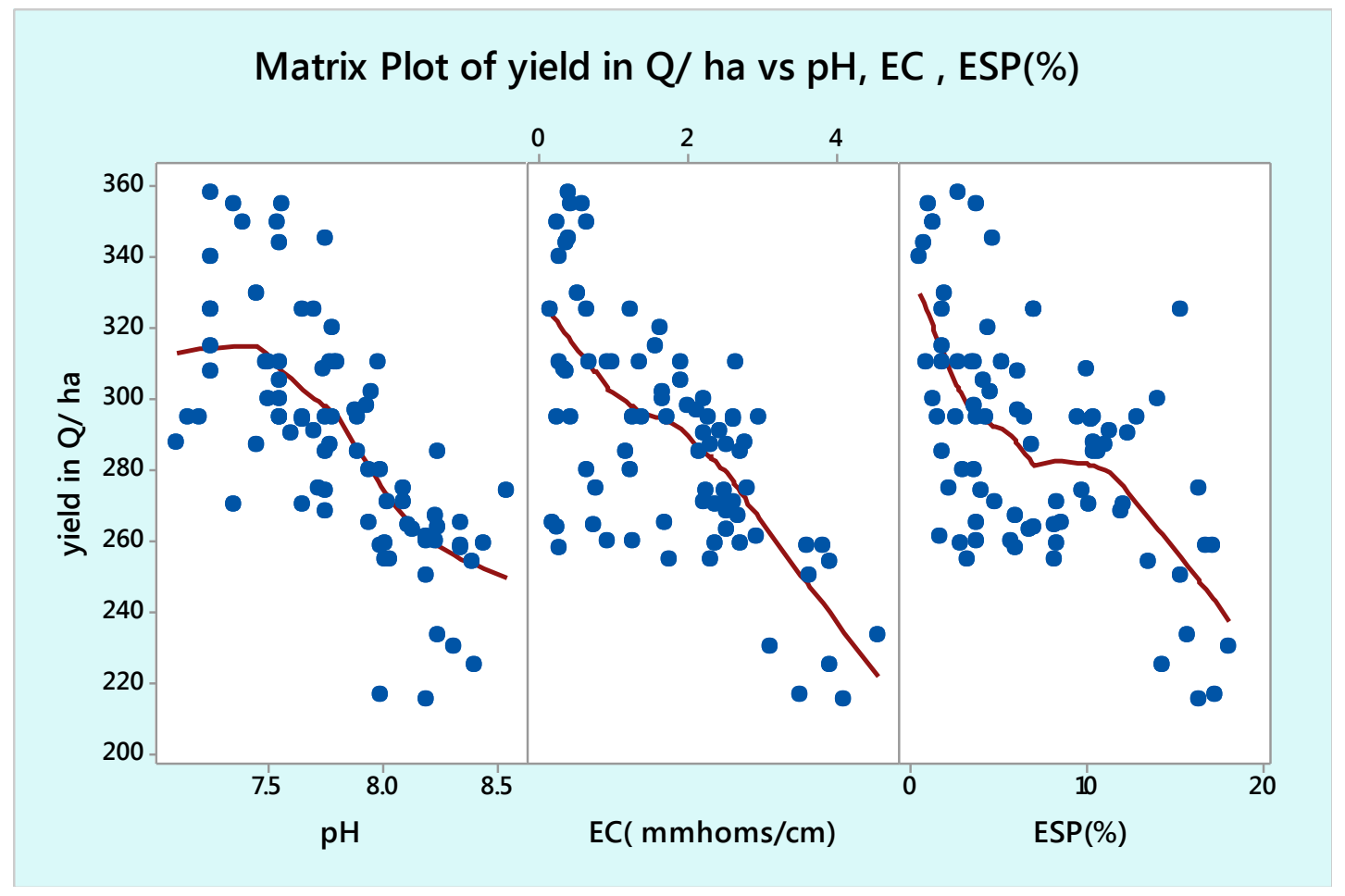

Crop yield showed a negative relationship with the level of soil $\mathrm{pH}$ (figure 9). Onion yield showed a decreasing trend as the level of $\mathrm{pH}$ increased to the alkaline. This was mainly due to the fact that the availability of some plant nutrients is greatly affected by soil $\mathrm{pH}$ (Halvin et al., 2002). It has been determined that most plant nutrients are optimally available to plants within 6.5 to $7.5 \mathrm{pH}$ range, plus this range of $\mathrm{pH}$ is generally very compatible to plant root growth (Anwar et al., 2004). At alkaline $\mathrm{pH}$ values, greater than $\mathrm{pH} 7.5$ for example, phosphate ions tend to react quickly with calcium $(\mathrm{Ca})$ and magnesium $(\mathrm{Mg})$ to form less soluble compounds. At acidic $\mathrm{pH}$ values, phosphate ions react with aluminum $(\mathrm{Al})$ and iron $(\mathrm{Fe})$ to again form less soluble compounds (Zia et al. (2006).

\subsection{Economic Analysis}

The partial budget analysis was done following the standard methodology designed by (CIMMYT, 1988) to select the most economically important soil salinity amendments. Accordingly, the maximum net benefit (780240.00Birr) was obtained by treatment 9 where 5t/ha Compost $+100 \%$ GR (4t/ha) was applied. However, the MRR was high (34.48birr) for treatment seven where 2.5t/ha compost was applied in combination with $4 \mathrm{t} / \mathrm{ha}$ gypsum. In this case, even though net benefit for the treatment 9 is higher as compared with the rest of the treatments, its MRR is lower than other treatments of combined application. The Marginal rate of return (MRR) measures the amount of benefit gained for additional unit of cost or investment. The net benefit showed an increasing trend as the level of compost and gypsum application was increasing. However, final recommendation will be based on the MRR that determine the profitability of an investment. Similar studies by Wienhold and Trooien (2005) and Abdel-Fattah (2012) reported that gypsum $(\mathrm{CaSO} 4 \cdot 2 \mathrm{H} 2 \mathrm{O})$ amendment is the most economical amendment used on sodic soil management. 
Kitila et al.

Table 4: Partial Economic analysis for onion yield

\begin{tabular}{lllllllll}
\hline Treatments & $\begin{array}{l}\text { Mean } \\
\text { yield in } \\
\text { Q/ha }\end{array}$ & $\begin{array}{l}\text { Input } \\
\text { cost /ha } \\
\text { (ETB) }\end{array}$ & $\begin{array}{l}\text { Labor } \\
\text { costs } \\
\text { /ha } \\
\text { (ETB) }\end{array}$ & $\begin{array}{l}\text { Total } \\
\text { variable } \\
\text { cost/ha } \\
\text { (ETB) }\end{array}$ & $\begin{array}{l}\text { Market } \\
\text { price of } \\
\text { Onion/Q } \\
\text { (ETB) }\end{array}$ & $\begin{array}{l}\text { Gross } \\
\text { income } \\
\text { ha }\end{array}$ & $\begin{array}{l}\text { Net income/ ha } \\
\text { in (ETB) }\end{array}$ & $\begin{array}{l}\text { MRR } \\
\text { (ETB) }\end{array}$ \\
\hline (control) & 237.18 & 36500 & 28020 & 64520 & 2000 & 474360.00 & 409840.00 & 0 \\
2.5t/ha compost & 250.55 & 36350 & 30520 & 66870 & 2000 & 501100.00 & 434230.00 & 10.38 \\
5t/ha compost & 275.55 & 36200 & 33020 & 69220 & 2000 & 551100.00 & 481880.00 & 15.33 \\
2t/ha Gypsum & 284.44 & 42100 & 28020 & 70120 & 2000 & 568880.00 & 498760.00 & 15.88 \\
$\begin{array}{l}\text { 4t/ha Gypsum } \\
\text { 2.5t/ha compost+2t/ha }\end{array}$ & 325.00 & 47700 & 28020 & 75720 & 2000 & 650000.00 & 574280.00 & 14.68 \\
$\begin{array}{l}\text { Gypsum } \\
\text { 2.5t/ha compost+4t/ha }\end{array}$ & 355.77 & 41950 & 30520 & 72470 & 2000 & 711540.00 & 639070.00 & 28.83 \\
$\begin{array}{l}\text { Gypsum } \\
\text { 5t/ha compost+2t/ha }\end{array}$ & 375.55 & 41800 & 30520 & 72320 & 2000 & 751100.00 & 678780.00 & 34.48 \\
$\begin{array}{l}\text { Gypsum } \\
\text { 5t/ha compost+4t/ha } \\
\text { Gypsum }\end{array}$ & 406.70 & 41800 & 33020 & 74820 & 2000 & 813400.00 & 738580.00 & 31.92 \\
\hline
\end{tabular}

\section{Conclusions and Recommendations}

Soil and plant health can be adversely affected by the presence of excessive salts in soils. Understanding how salt-affected soils develop and identifying their characteristics is crucial to managing salt affected areas. Choosing which management techniques to employ to salt-affected soils will depend on the nature and extent of the problem, cost and available resources.

This project was conducted with the aim to reduce the effect of soil sodicity problem on onion yield through the application of compost and gypsum. An effective reclamation procedure for sodic soils is removal of undesirable $\mathrm{Na}^{+}$concentration in the soil by application of some $\mathrm{Ca}^{2+}$ source like gypsum. Accordingly, the combination of compost and gypsum proved to be the best soil amendment for reducing soil pH, ESP and EC of the soil. In addition, with increasing rate of the application of gypsum and compost used in reclamation process, the more decrease in soil salinity problem and increased in crop yield. Application of compost also played an important role in improving soil $\mathrm{pH}$ that directly affects the availability of major plant nutrients.

\section{References}

Abay Challa Kuke and Kasahun Kitila Hunde. 2019. Evaluation of Water Hyacinth (Eichhornia Crassipes) Compost for Its Nutrient Content at
Therefore, based on the above findings, it was highly recommended to apply the combination of compost and gypsum for reclamation of salt affected soil. Accordingly, based on the marginal rate of return calculated for the treatments, farmers and other beneficiaries were recommended to effectively reclaim their salt affected soils by applying gypsum at the full rate $(100 \%$ GR) integrating it with compost $(2.5 \mathrm{t} / \mathrm{ha})$ where 34.48birr was gained higher than the remaining treatments..

\section{Acknowledgment}

The authors are grateful to IQQO for funding the project. The authors would also like to thank Adami Tulu Agricultural Research Center for providing materials and playing every facilitation role from the beginning to the end of the project. Finally, we would like to appreciate the contribution of technical and field assistances, Gebremikael Adera, Jamal Qure, and Abdo Oshe for their strong effort in site management from land preparation to harvesting and data collection.

Adami Tulu Agricultural Research Center". Innovative Techniques in Agriculture 3(4): 690-696 Abbas G, Saqib M, Akhtar J, Murtaza G, Shahid M and Hussain A. 2016. Relationship between rhizosphere acidification and phytoremediation in 
two acacia species. J. Soil Sediments. 16 (4):13921399.

Abdel- Fattah MK. 2012. Role of gypsum and compost in reclaiming saline-sodic soils. J. Agric. Vet.Sci. 1(3): 3038 .

Ameen A, Ahmad J and Raza S. 2017. Effect of compost and gypsum on rice crop production in saline soil. Int. J. Adv. Sci. Res. 3(08): 99-100.

Anwar SA, Ibrahim M, Ishaq M, and Ahmed N. 2004. Use of sulphuric acid on normal calcareous soils. In: Abstracts 10th Int. Congr. Soil Science Society of Pakistan. Tandojam.

Bardhan G, Chaudhar, I SK and Mohapatra PK. 2007. Effect of irrigation water quality on saturated hydraulic conductivity of typic haplustert, vertic haplustept, and lithic ustorthent, Soil J. Agric. Phys. 7: 38-46. DOI:10.1111.

Brady N and Weil R. 2002. The Nature and Properties of Soils, 13th Edition. Prentice Hall. Upper Saddle River, New Jersey. 960p.

Chintala R, McDonald L. M, and Bryan WB. 2010. Grouping soils by taxonomy order to improve lime recommendations. Commun. Soil Sci. Plant 41:1594-1603.

CIMMYT (International Maize and Wheat Improvement center).1988. An Economic Training Manual: from agronomic data recordation. CYMMT. Mexico. 79 pp Delassa Angassa

Clark G, Dodgshun N, Sale P and Tang C. 2007. Changes in chemi cal and biological properties of a sodic clay subsoil with addition of organic amendments. Soil Biology and Biochemistry 39: 2806-2817.

El-Sanat GMA, Aiad MA and Amer MM. 2017. Impact of some soil amendments and different tillage depths on saline heavy clay soils properties and its yield water productivity. International Journal of Plant and Soil Science 14(2): 1-13

Farook A, Khan MD. 2010. Response of mineral nutrient of rice to sulfidic material as sulphur fertilizer. Nat. and Sci. J., 8: 31-40

Fisher M. 2011. Amending soils with gypsum. Crops \& Soils magazine, Nov.-Dec. 2011, American Soc. of Agron.,

Ghafoor A, Murtaza G, Ahmad B and Boers TM. 2008. Evalu ation of amelioration treatments and economic aspects of using saline-sodic water for rice and wheat production on salt affected soils under arid land conditions. Irrigation and Drainage, 57: 424-434.

Gonzalez NLM, Toth T and Garcia D. 2004. Integrated management for sustainable use of salt affected soils in Cuba, Universidad Y Ciencia, 20 (40): 86102

Halvin JL, Beaton J, Tisdale SL and Nelson WL. 2002. Soil Acidity and Alkalinity, in Soil Fertility and
Fertilizers; an Introduction to Nutrient Management. 6th Ed. Prentice Hall, New York

Islam MA, Islam S, Akter A and Rahman MH. 2017. Effect of Organic and Inorganic Fertilizers on Soil Properties and the Growth, Yield and Quality of Tomato in Mymensingh. Bang. Agri. 7 (18): 2-7

Jim M. 2002. Managing Salt Affected Soils, NRCS, South Dakota

Joachim HJR, Makoi and Ndakidemi PA. 2007. Reclamation of sodic soils in northern Tanzania, using locally available organic and inorganic resources, African Journal of Biotechnology 6(16):1926-1931

Kasahun Kitila, Ayub Jalde and Workina M. 2016. Evaluation and Characterization of Soil Salinity Status at Small-Scale Irrigation Farms at Bora and Lume Districts of East Showa Zone, Oromia, Ethiopia. Science Journal of Analytical Chemistry. 4(6):95-102. doi: 10.11648/j.sjac.20160406.13

Mohamed ES, Morgun EG and Goma SM. 2011. Assessment of soil salinity in the Eastern Nile Delta (Egypt) using Geoinformation techniques. Moscow Univ. Soil Sci. Bull. 66(1):11-14. http://dx.doi.org/10.3103/S0147687411010030

Mokoi J and Verplancke H. 2010. Effect of gypsum placement on the physical properties of a saline sandy loam soil. Aust. J Crop Sci. 4: 556-563.

Moukhtar MM, El-Arquan MYS, El-Hadidy EM and El-Shewikh MAB. 2003. Amelioration of salt affected soils in north Dakhlia Governorate through application of tile drainage and subsoiling. J.Agric. Sci. Mansoura Univ., Special Issue, Sci. Symp. On problems of soils and waters in Dakhlia and Damietta Governorate. March 18.

Muhammad Anwar Zaka, Khalil Ahmed, Hafeezullah Rafa, Muhammad Sarfraz, Helge Schmeisk. 2018. Effectiveness of compost and gypsum for amelioration of saline sodic soil in rice wheat cropping system. Asian J Agri \& Biol. 6(4):514523

Niazi BH, Ahmed M, Hussain N, Salim M. 2001. Comparison of sand, gypsum and sulphuric acid to reclaim a dense saline sodic soil. Int. J. Agric. Biol. 3(3): 316-318

Qadir M, Tubeileh A, Akhtar J, Larbi A, Minhas PS and Khan MA. 2008. Productivity enhancement of salt-affected environments through crop diversification. Land Deg. Devel., 19: 429-453

Rodriguez-Navarro A and Rubio F. 2006. High-affinity potassium and sodium transport systems in plants. J. Exp. Bot. 57: 1149-1160. http://dx.doi.org/10.1093/jxb/erj068

Saied MM, Elsanat GM, Talha, NI and El Barbary SM. 2017. On- Farm Soil Management Practices for Improving Soil Properties and Productivity of 
Rice and Wheat under Salt-Affected Soils at North Delta. Egypt J. Soil Sci. 57 (4): 445 - 453.

Shaaban M, Abid M and Abou S. 2013. Amelioration of salt affected soils in rice paddy system by application of organic and inorganic amendments. Plant Soil Environ 59(5): 227-233.

Sharma BR and Minhas PS. 2005. Strategies for managing saline/alkali waters for sustainable agricultural production in South Asia. Agric. Water Manag. 78: 136-151. http://dx.doi.org/10.1016/j.agwat.2005.04.019

Tamirie H. 2004. Desertification in Ethiopian highlands, Norwegian Church Regional Senior Consultant on Environment and Natural Resource Management, Report No. 200, Addis Ababa, Ethiopia.

Tejada M, Garcia C, Gonzalez JL and Hernandez MT. 2006. Use of organic amendment as a strategy for saline soil remediation: Influence on the physical, chemical and biological properties of soil. Soil Biol Biochem 38:1413-1421

Wienhold BR and Trooien TP. 2005. Salinity and sodicity changes under irrigated alfalfa in the Northern Great Plains. Soil Sci. Soc. Am. J. 59: 1709-1714.

Wong VNL, Dalal RC, Greene RSB. 2009. Carbon dynamics of sodic and saline soil following gypsum and organic material additions: $A$ laboratory incubation. Appl Soil Ecol 41:29-40

Wright AL, Provin TL, Hons FM, Zuberer DA and White RH. 2018. Compost Impacts on Sodicity and Salinity in a Sandy Loam Turf Grass Soil. Compost Sci. Util. 16(1): 30-35

Zaka MA, Mujeeb F, Sarwar G Hassan NM and Hassan G. 2003. Agromelioration of Saline Sodic soils. Online J. Biol. Sci. 3(3): 329-334.

Zia MH, Ghafoor A, Saifullah TH and Boers M. 2006. Comparison of sulphurous acid generator and alternate amendments to improve the quality of salinesodic water for sustainable rice yields. Paddy Water Environment 4: 153-162. 